九州大学学術情報リポジトリ

Kyushu University Institutional Repository

Effect of Soil Characteristics and Potassium Application Rate on the Plant-Absorbable Potassium Forms and Transport Mechanisms in So il

Mori, Yuki

Laboratory of Environmental Geochemistry, Division of Bioproduction Environmental Sciences, Department of Agro-Environmental Sciences, Faculty of Agriculture, Kyushu University

Yoshida, Minako

Laboratory of Environmental Geochemistry, Division of Bioproduction Environmental Sciences, Department of Agro-Environmental Sciences, Graduate School of Bioresource and Bioenvironmental Sciences, Kyushu University

Wada, Shin-ichiro

Laboratory of Environmental Geochemistry, Division of Bioproduction Environmental Sciences, Department of Agro-Environmental Sciences, Faculty of Agriculture, Kyushu University

https://doi.org/10.5109/25210

出版情報：九州大学大学院農学研究院紀要. 57 (2)，pp.485-488，2012-09-20. Faculty of Agriculture, Kyushu University

バージョン :

権利関係 : 


\title{
Effect of Soil Characteristics and Potassium Application Rate on the Plant-Absorbable Potassium Forms and Transport Mechanisms in Soil
}

\author{
Yuki MORI*, Minako YOSHIDA ${ }^{1}$ and Shin-Ichiro WADA
}

\author{
Laboratory of Environmental Geochemistry, Division of Bioproduction Environmental Sciences, \\ Department of Agro-Environmental Sciences, Faculty of Agriculture, \\ Kyushu University, Fukuoka 812-8581, Japan \\ (Received April 27, 2012 and accepted May 10, 2012)
}

\begin{abstract}
Although the demand for saving potassium (K) fertilizer application is increasing, the evaluation of available $\mathrm{K}$ by exchangeable $\mathrm{K}$ that is operationally defined as $1 \mathrm{M}$ ammonium acetate-extractable $\mathrm{K}$ has limitations. In order to investigate the contribution of soil $\mathrm{K}$ forms and transport mechanisms for $\mathrm{K}$ uptake, pot experiment was performed using two soils with varying $\mathrm{K}$ application rate. The spinach grown in vermiculite-rich soil absorbed considerable amount of $\mathrm{K}$ from nonexchangeable fraction and the transport mechanism was mainly by diffusion, whereas the plant cultivated in volcanic ash soil, which contain less vermiculite, mostly absorbed exchangeable $\mathrm{K}$ and the contribution of mass flow was substantially high. Exchangeable $\mathrm{K}$ and soil solution $\mathrm{K}$ in vermiculite-rich soil did not much increased at the high rate of $\mathrm{K}$ application. A part of applied K might become readily absorbable-nonexchangeable K. To evaluate $\mathrm{K}$ supplying capacity of soil, it is necessary to quantify not only exchangeable $\mathrm{K}$ but also the $\mathrm{K}$ fixation and the amount of $\mathrm{K}$ released from nonexchangeable sites. In soil whose $\mathrm{K}$ fixation capacity is low, the transport of $\mathrm{K}$ from soil might be modeled by solute transport and cation exchange.
\end{abstract}

Keywords: diffusion, exchangeable K, mass flow, nonexchangeable K, potassium

\section{INTRODUCTION}

Potassium (K) is one of the most important elements that are supplied as fertilizer as well as nitrogen and phosphorus. The price of potash fertilizer drastically increased recently and the demand for saving $\mathrm{K}$ application is increasing. Actually, however, $\mathrm{K}$ has accumulated in many Japanese agricultural fields (Obara and Nakai, 2003) because excessive amounts of $K$ have been applied for a long time. For these reasons, the evaluation of $\mathrm{K}$ supplying capacity of soil is becoming very important in order to utilize accumulated $\mathrm{K}$ in soils and to apply $\mathrm{K}$ fertilizer effectively.

In many countries, $1 \mathrm{M}$ ammonium acetate extractable $\mathrm{K}$, which is defined as exchangeable $\mathrm{K}$, has been used as a measure for available $\mathrm{K}$ in soil. However, some soils contain large amounts of nonexchangeable $\mathrm{K}$ and plants are known to absorb a part of the nonexchangeable K (Krishnakumari et al., 1984; Memon et al., 1988; Moritsuka et al., 2004). Although some methods for determining nonexchangeable $\mathrm{K}$ were proposed (Dhillon and Dhillon, 1990; Helmke and Sparks, 1996; Cox et al., 1999; Moristuka et al., 2003), they are not used often due to complicated procedure or low reliability of the results.

The solute transport process from bulk soil to plant root surface are also important for determining soil K supplying capacity. The solute transport process in soil

\footnotetext{
1 Laboratory of Environmental Geochemistry, Division of Bioproduction Environmental Sciences, Department of AgroEnvironmental Sciences, Graduate School of Bioresource and Bioenvironmental Sciences, Kyushu University

* Corresponding Author (E-mail: y-mori@agr.kyushu-u.ac.jp)
}

comprises interception, mass flow and diffusion (Barber, 1968). Soil K was considered to transfer to root surface mainly by diffusion (Baligar, 1985). However, it is possible that contribution of mass flow increase in $\mathrm{K}$ accumulated soil in which $\mathrm{K}$ concentration of soil solution is high.

In order to predict $\mathrm{K}$ uptake by plant, the modeling of soil $\mathrm{K}$ transport to root surface is useful. Although some models have been proposed to predict $\mathrm{K}$ uptake by plant (Claassen, 1986; Samal, 2010), there is no model that is able to use in practical soil management. This is because contribution of nonexchangeable form $\mathrm{K}$ or the transport mechanisms are not understood enough to construct desired model.

In this study, the contribution of the two forms of soil $\mathrm{K}$ and transport mechanisms to $\mathrm{K}$ uptake was investigated by pot experiments using two soils with varying $\mathrm{K}$ application. The effects of soil properties on the plantabsorbable potassium forms and transport processes were discussed.

\section{MATERIALS AND METHODS}

\section{Soil samples}

Two soil samples were collected from non-agricultural field in Fukuoka, Yoshiki and from pastureland in Kumamoto, Koshi. The Koshi soil was a volcanic ash soil. The soil samples were air-dried and crashed and passed $4.75-\mathrm{mm}$ screen for cultivation experiment and passed $2-\mathrm{mm}$ screen for soil analyses.

The soil samples were analyzed for exchangeable cations, nonexchangeable $\mathrm{K}$, clay content, and mineral composition. Exchangeable cations were determined by $\mathrm{pH} 7$, $1 \mathrm{M}$ ammonium acetate extraction. Effective cation exchange capacity (ECEC) was calculated following 
Sumner and Miller (1996). Nonexchangeable K was extracted by boiling soil sample with $1 \mathrm{M}$ nitric acid (Helmke and Sparks, 1996). Concentrations of $\mathrm{Ca}, \mathrm{Mg}$, $\mathrm{K}, \mathrm{Na}$ in the soil extractions were measured by atomic adsorption spectrometer (Hitachi, Z-2300). Clay fraction was collected by sedimentation method following organic matter decomposition with $\mathrm{H}_{2} \mathrm{O}_{2}$ and clay content was determined by weighing. Mineral composition of the clay fractions was determined by X-ray diffraction (Rigaku, RINT-2100V).

\section{Cultivation experiment}

Cultivation experiment was performed in Phytotron I (A3) of Biotron Application Center in Kyushu University. Potassium was applied as potassium chloride at the rate of $0,50,250 \mathrm{mg} \mathrm{K} \mathrm{kg}^{-1}$. Nitrogen was applied as ammonium nitrate at the rate of $300 \mathrm{mg} \mathrm{N} \mathrm{kg}^{-1}$ for Yoshiki soil and $150 \mathrm{mg} \mathrm{N} \mathrm{kg}^{-1}$ for Koshi soil. Phosphorus was applied as calcium dihydrogenphosphate at the rate of $55 \mathrm{mg} \mathrm{P}$ $\mathrm{kg}^{-1}$ for Yoshiki Soil and $275 \mathrm{mg} \mathrm{P} \mathrm{kg}^{-1}$ for Koshi soil. The fertilization amounts were determined by preliminary experiments. Three liters of soil samples were placed in 1/5000 Wagner pots and watered to make moisture content to $40 \%$ of field capacity (FC). The moisture content was kept by adding deionized water every day. Six seeds of Spinacia oleracea were sawed in each pot. After germination, Spinacia oleracea were thinned to 3 plants/pot. The pots were covered with polyethylene film in order to prevent water evaporation from soil surface and the amount of transpiration was measured by weighing the pots. The plants were cultivated from August 17 to October 14 in 2011. The experiment was performed in triplicate.

After cultivation, plants were dried at $70^{\circ} \mathrm{C}$ in oven for $24 \mathrm{~h}$ and weighed. Dried plant samples were milled and digested using $\mathrm{HNO}_{3}-\mathrm{H}_{2} \mathrm{O}_{2}$ in Teflon beaker on a hot plate. Soil samples collected before and after cultivation were air-dried and $1 \mathrm{M}$ ammonium acetate-extractable $\mathrm{K}$ and soil solution $\mathrm{K}$ were analyzed. It was impossible to collect soil solution from 40\% FC soil samples, therefore water was added to soil to make water content to $100 \%$ FC and then soil solution was collected by centrifugation method ( $\mathrm{pF}$ 3.5). The concentrations of $\mathrm{K}$ measured under 100\% FC were multiplied by a factor of 2.5 to simply estimate those of soil solution under $40 \%$ $\mathrm{FC}$ condition. $\mathrm{K}$ concentrations in plant digestion and soil extraction were measured by atomic adsorption spectrometer (Hitachi, Z-2300).

\section{Estimation of absorbed form and transport mecha- nisms of $K$}

The amount of exchangeable $\mathrm{K}$ absorbed by plant was estimated from the decrease of exchangeable $\mathrm{K}$ after cultivation. Absorbed nonexchangeable $\mathrm{K}$ was calculated from the difference between total $\mathrm{K}$ uptake and absorbed exchangeable K. The potassium transported by mass flow was estimated by multiplying mean concentration of soil solution $\mathrm{K}$ with transpiration (Addiscott and Talibudeo, 1971). The potassium transported by diffusion was calculated by subtracting the amount of $\mathrm{K}$ transferred by mass flow from the total $\mathrm{K}$ uptake. The contribution of interception was neglected in this experiment, because its contribution was considered quite low (Baligar, 1985).

\section{RESULTS AND DISCUSSION}

The soil properties were shown in Table 1. Exchangeable K and ECEC were higher in the Koshi soil than in the Yoshiki soil. The content of exchangeable $\mathrm{K}$ in the Yoshiki soil was lower than the soil quality stand-

Table 1. Soil properties of the Yoshiki and Koshi soils

\begin{tabular}{|c|c|c|c|c|c|c|c|c|}
\hline \multirow[t]{2}{*}{ Sample } & \multicolumn{4}{|c|}{$\begin{array}{l}\text { Excgabgeable Cation } \\
\quad(\mathrm{cmol} / \mathrm{kg})\end{array}$} & \multirow{2}{*}{$\begin{array}{c}\text { ECEC } \\
\left(\mathrm{cmol}_{\mathrm{c}} / \mathrm{kg}\right)\end{array}$} & \multirow{2}{*}{$\begin{array}{c}1 \mathrm{M} \mathrm{HNO}_{3} \\
\text { extractable K } \\
(\mathrm{mg} / \mathrm{kg})\end{array}$} & \multirow{2}{*}{$\begin{array}{c}\text { Clay } \\
\text { Content } \\
(\%)\end{array}$} & \multirow{2}{*}{$\begin{array}{c}\text { Soil } \\
\text { Minerals }\end{array}$} \\
\hline & $\mathrm{Ca}$ & $\mathrm{Mg}$ & K & $\mathrm{Na}$ & & & & \\
\hline Yoshiki & 3.5 & 1.8 & 0.3 & 0.2 & 10.9 & 892 & 7.9 & $\mathrm{Vt}, \mathrm{Kt}>\mathrm{Ch}$ \\
\hline Koshi & 8.7 & 2.2 & 2.0 & 0.1 & 22.9 & 228 & 25.8 & $\begin{array}{c}\text { amorphous } \\
(\mathrm{Kt},>\mathrm{Ch}, \mathrm{Ch}-\mathrm{Vt})\end{array}$ \\
\hline
\end{tabular}

ECEC: effective cation exchange capacity

Vt: vermiculite, Kt: kaolinite, Ch: chlorite, Ch-Vt: chlorite-vermiculite intermediate

Table 2. Exchangeable $\mathrm{K}$ and soil solution $\mathrm{K}$ before and after cultivation

\begin{tabular}{|c|c|c|c|c|c|}
\hline \multirow[t]{2}{*}{ Sample } & \multirow{2}{*}{$\begin{array}{c}\text { K Application } \\
\text { (mg/kg) }\end{array}$} & \multicolumn{2}{|c|}{$\begin{array}{c}\text { Exchangeable K } \\
(\mathrm{mg} / \mathrm{kg})\end{array}$} & \multicolumn{2}{|c|}{$\begin{array}{l}\text { Soil Solution K } \\
\quad(\mathrm{mg} / \mathrm{L})\end{array}$} \\
\hline & & Before & After & Before & After \\
\hline \multirow[t]{3}{*}{ Yoshiki } & 0 & 134 & 90 & 28 & 10 \\
\hline & 50 & 126 & 89 & 36 & 14 \\
\hline & 250 & 146 & 111 & 60 & 26 \\
\hline \multirow[t]{3}{*}{ Koshi } & 0 & 763 & 585 & 281 & 166 \\
\hline & 50 & 816 & 694 & 342 & 239 \\
\hline & 250 & 984 & 883 & 503 & 285 \\
\hline
\end{tabular}


ard proposed by Fukuoka prefecture. On the other hand, $1 \mathrm{M} \mathrm{HNO}_{3}$ extractable $\mathrm{K}$ (nonexchangeable $\mathrm{K}$ ) was much higher in the Yoshiki soil than in the Koshi soil. The high content of nonexchangeable $\mathrm{K}$ is probably due to the high content of vermiculite, which fixes potassium in its interlayer spaces. The clay fraction of the Koshi soil was mainly consisted of non-crystalline minerals and contained less nonexchangeable $\mathrm{K}$.

In addition to low concentration of exchangeable $\mathrm{K}$ in the Yoshiki soil, the application of $\mathrm{K}$ little increased the exchangeable $\mathrm{K}$ and soil solution $\mathrm{K}$ (Table 2). The $\mathrm{K}$ applied to the Yoshiki soil was assumed to have become nonexchangeable form. On the other hand, the most of $\mathrm{K}$ applied to the Koshi soil retained as exchangeable $\mathrm{K}$. Both the concentration and increment of soil solution $\mathrm{K}$ in the Koshi soil after $\mathrm{K}$ application were much higher than in the Yoshiki soil. The concentrations of exchangeable $\mathrm{K}$ and soil solution $\mathrm{K}$ decreased in all treatments after cultivation.

The dry mass of cultivated plant differed significantly between two soils $(p<0.05)$ whereas the differences among $\mathrm{K}$ application were not significant (Fig. 1). Although the dry masses of plant grown in the Yoshiki soil were higher than in the Koshi soil, K concentrations of the plants grown in the Koshi soil were higher than in the Yoshiki soil, indicating that these two soils contained sufficient $\mathrm{K}$ for plant growth. The $\mathrm{K}$ concentration of plant grown in the Yoshiki soil increased as K application increased, whereas no clear tendency was observed in Koshi soil. The amounts of transpiration during plant grown in the Yoshiki soil were higher than those in the Koshi soil.

The contribution of exchangeable $\mathrm{K}$ to plant uptake was much higher in the Koshi soil than in the Yoshiki soil (Fig. 2). The contribution of nonexchangeable $\mathrm{K}$ increased as $\mathrm{K}$ application rate increased in both soils. This might be because a part of applied $\mathrm{K}$ became relatively easily absorbable nonexchangeable $\mathrm{K}$.

The contribution of mass flow for total uptake $\mathrm{K}$ in the Yoshiki soil was very low (Fig. 3), which reflected the low concentration of $\mathrm{K}$ in the soil solution (Table 2).
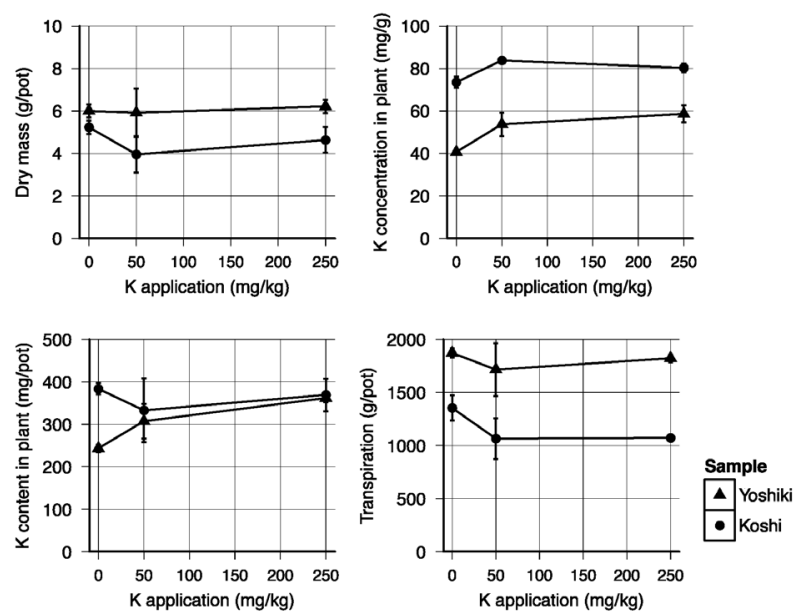

Fig. 1. Dry mass, the amount of uptake $K$ and transpiration of spinach. The error bars represent the standard error of the mean.
The contribution of mass flow in the Koshi soil was higher than in the Yoshiki soil. All absorbed $\mathrm{K}$ was estimated to have transferred to plant in the Koshi soil in which $\mathrm{K}$ application was $250 \mathrm{mg} \mathrm{K} \mathrm{kg}^{-1}$. Although it is difficult to discuss the transport mechanisms quantitatively because the estimation of the contribution of mass flow may include some errors, it is obvious that soil properties such as mineral composition, the content of nonexchangeable $\mathrm{K}$ and soil solution $\mathrm{K}$ affected the transport mechanism of $\mathrm{K}$.

In the Yoshiki soil, the level of exchangeable $\mathrm{K}$ was lower than that defined in the soil quality standard and the $\mathrm{K}$ application did not much increase the amount of the exchangeable K. In such soil, it is highly probable that increasing exchangeable $\mathrm{K}$ by fertilizer application is difficult. Nevertheless, plants grew normally (Fig. 1). In addition, the $\mathrm{K}$ concentration in plant rose as $\mathrm{K}$ application increased in spite of the unchanged level of exchangeable K (Fig. 4). For these reasons, not only exchangeable $\mathrm{K}$ but also nonexchangeable $\mathrm{K}$ and $\mathrm{K}$ fixation should be considered to make an economic fertilizer recommendation.

On the other hand, the Koshi soil did not contain much nonexchangeable $\mathrm{K}$ and vermiculite that could fix applied K. Most of applied $\mathrm{K}$ was retained as exchangeable $\mathrm{K}$ and the soil solution $\mathrm{K}$ largely increased as $\mathrm{K}$ application rate increased. However, absorption from nonexchangeable fraction was observed from the intensively K applied Koshi soil (Fig. 2). This can be explained by that the dissolution of nonexchangeable $\mathrm{K}$ paralleled the mass flow by ion accumulation or $\mathrm{K}$ depletion in rhizospere soil solution (Moritsuka et al., 2004; Gregory, 2005). Because the contribution of mass flow was quite
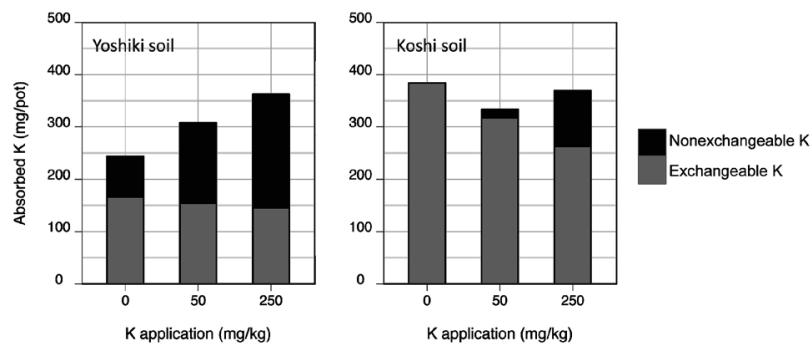

Fig. 2. The amount of uptake $\mathrm{K}$ attributed to exchangeable and nonexchangeable $\mathrm{K}$.
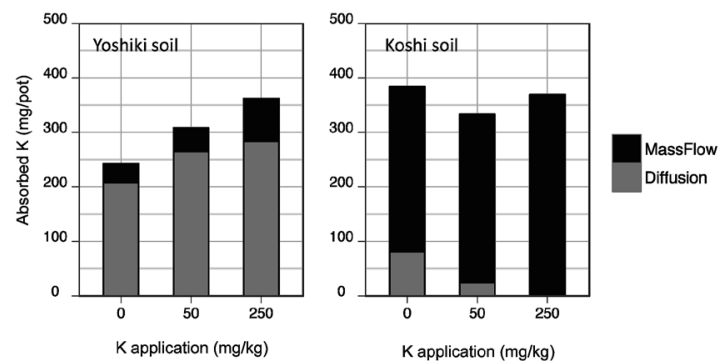

Fig. 3. The amount of uptake $\mathrm{K}$ attributed to mass flow and diffusion. 


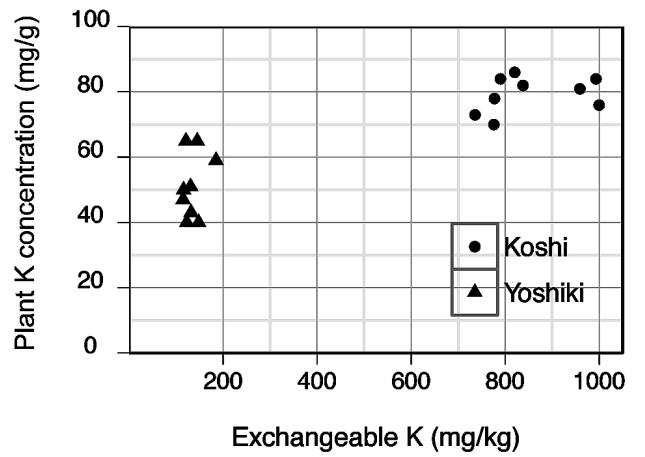

Fig. 4. The relationship between exchangeable $\mathrm{K}$ before cultivation and $\mathrm{K}$ concentration of spinach. The data obtained from all replicates are plotted.

high for plant $\mathrm{K}$ uptake in the Koshi soil, the transport of $\mathrm{K}$ in soils not containing much amount of nonexchangeable $\mathrm{K}$ might be modeled by solute transport and cation exchange between exchangeable $\mathrm{K}$ and soil solution $\mathrm{K}$.

In this study, rhizosphere soil was not treated separately. However, it was reported that the decrease of exchangeable and nonexchangeable $\mathrm{K}$ in rhizosphere was higher than in bulk soil (Gregory, 2006). In addition, besides soil properties, plant species also affect the extent of availability of nonexchangeable $\mathrm{K}$ (Memon, 1988). Changes of $\mathrm{K}$ in rhizosphere and effect of plant species should be considered in modeling the dynamics of nonexchangeable $\mathrm{K}$ and $\mathrm{K}$ transport in soils in future.

\section{CONCLUSION}

Soil characteristics affected the amount of plantabsorbable $\mathrm{K}$ form and transport mechanism of $\mathrm{K}$. In the Yoshiki soil, $\mathrm{K}$ application did not much increase exchangeable $\mathrm{K}$ and soil solution $\mathrm{K}$ because of $\mathrm{K}$ fixation. Plant absorbed considerable amount of nonexchangeable $\mathrm{K}$ from the Yoshiki soil and contribution of diffusion was larger than mass flow. On the other hand, the Koshi soil did not contain much amount of nonexchangeable $\mathrm{K}$, and both exchangeable $\mathrm{K}$ and soil solution $\mathrm{K}$ largely increased after $\mathrm{K}$ application. Furthermore, the contribution of mass flow to $\mathrm{K}$ uptake was very high. In both soils, a part of applied $\mathrm{K}$ was assumed to have become easily absorbable nonexchangeable $\mathrm{K}$. To evaluate $\mathrm{K}$ supplying capacity of soil or modeling $\mathrm{K}$ absorption, it is necessary to quantify the $\mathrm{K}$ fixation and the amount of $\mathrm{K}$ released from nonexchangeable sites. In a soil whose $\mathrm{K}$ fixation capacity is low, the transport of $\mathrm{K}$ from soil might be modeled by considering solute transport and cation exchange.

\section{ACKNOWLEDGEMENTS}

This work was supported by the Grants-in-Aid for Scientific Research B (21380048). The authors would like to thank to S. Fujitomi, Ph. D., from Fukuoka Agricultural Research Center and H. Kubotera, Ph. D., from National
Agricultural Research Center for Kyushu Okinawa Region for giving soil samples. We are grateful to the Biotron Application Center at Kyushu University for supporting our cultivation experiment.

\section{REFERENCES}

Addiscottm, T. M. and O. Talibudeo 1971 Transport of potassium to ryegrass roots in soils with and without added potassium. J. Agric. Sci., 76: 411-418

Baligar, V. C. 1985 Potassium uptake by plants, as characterized by root density, species and K/Rb ratio. Plant and Soil, 85: $43-53$

Barber, S. A. 1995 Soil nutrient bioavailability : a mechanistic approach. (2nd edition) John Wiley, New York (USA), pp. 231-261

Barber, S. A., J. M. Walker and E. H. Vasey 1963 Mechanism for the Movement of Plant Nutrients from the Soil and Fertilizer to the Plant Roots. J. Agric. food Chem., 11: 204-207

Claassen, N., K. Syring and A. Jungk 1986 Verification of a mathematical-model by simulating potassium uptake from soil. Plant Soil, 95: 209-220

Cox, A., B. Joern, S. Brouder and D. Gao 1999 Plant-available potassium assessment with a modified sodium tetraphenylboron method. Soil Sci. Soc. of Am. J., 63: 902-911

Dhillon, S. and K. Dhillon 1990 Kinetics of release of nonexchangeable potassium by cation-saturated resins from red (Alfisols), Black (Vertisols) and Alluvial (Inceptisols) soils of India. Geoderma, 47: 283-300

Gregory, P. 2006 Plant Roots. Blackwell Publishing, Oxford (UK), pp. 223-227

Helmke, P. A. and D. L. Sparks 1996 Litium, Sodium, Potassium, Rubidium, and Cesium. In "Method of Soil Analysis Part 3 : Chemical Methods” ed. by D. L. Sparks, Soil Science Society of America Inc., Madison, WI (USA), pp. 551-574

Krishnakumari, M., M. S. Khera and A. B. Ghosh 1984 Studies on potassium release in an Inceptisoil (HolambiSeries) at the minimum level of exchangeable potassium. Plant Soil, $\mathbf{7 9}$ $3-10$

Memon, Y. M., I. F. Fergus, J. D. Hughes and D. W. Page 1988 Utilization of non-exchangeable soil potassium in relation to soil type, plant species and stage of growth. Aust. J. Soil Res., 26: 489-496

Mengel, K. and E. A. Kirkby 1980 Potassum in crop product. Adv. Agron., 33: 59-110

Moritsuka, N., J. Yanai, A. Fujii, S. Sano and T. Kosaki 2003 Evaluation of readily available nonexchangeable potassium in soil by sequential extractions with 0.01 molar hydrochloric acid. Soil Sci. Plant Nutr., 49: 631-639

Moritsuka, N., J. Yanai and T. Kosaki 2004 Possible processes releasing nonexchangeable potassium from the rhizosphere of maize. Plant and Soil, 258: 261-268

Obara, H. and M. Nakai 2003 Exchangeable bases and related soil properties of arable lands in Japan changes of soil characteristics in Japanese arable lands (I). Jpn. J. Soil Sci. Plant Nutr., 74: 615-622 (In Japanese)

Samal, D., J. L. Kovar, B. Steingrobe, U. S. Sadana, P. S. Bhadoria and N. Claassen 2010 Potassium uptake efficiency and dynamics in the rhizosphere of maize (Zea mays L.), wheat (Triticum aestivum L.), and sugar beet (Beta vulgaris L.) evaluated with a mechanistic model. Plant and Soil, 332 $1-17$

Sumner M. E. and W. P. Miller 1996 Cation exchange capacity and exchange coefficients. In "Method of Soil Analysis Part 3: Chemical Methods" ed. by D. L. Sparks, Soil Science Society of America Inc., Madison, WI (USA), pp. 1221-1222 